\title{
Investigating the relationship between service quality and customer satisfaction of BKash in Bangladesh
}

\section{Abdul Gaffar Khan*, Md. Shahed Mahmud and Reshma Pervin Lima}

Department of Business Administration,

Mawlana Bhashani Science and Technology University,

Tangail, Bangladesh

Email: gaffar.mbaiu@gmail.com

Email: shahed.m.mbstu@gmail.com

Email: reshma.pervin973@gmail.com

*Corresponding author

\begin{abstract}
The purpose of this paper is to investigate the relationship between service quality and customer satisfaction to use BKash through structural equation modelling. BKash is one of the leading mobile banking services providers in Bangladesh. A structured survey questionnaire was used to collect data from BKash users in Bangladesh. A convenience sampling method was used to select potential participants in this study. Out of the distributed questions, 292 completed usable were selected for the analysis which employed Partial Least Squares-Structural Equation Modelling (PLS-SEM). The results show that there exist positive and significant relationships between all variables of service quality and customer satisfaction for using BKash. Among the measurement variables the responsiveness and empathy have a strong impact on customer satisfaction, whereas tangibility was identified as a less significant factor in customer satisfaction. This study has several implications for researchers, financial policymakers, and senior management from banking industry for rendering and upgrading services to end-users and customers of mobile banking.
\end{abstract}

Keywords: mobile banking; service quality; customer satisfaction; SERVQUAL model; BKash.

Reference to this paper should be made as follows: Khan, A.G., Mahmud, M.S. and Lima, R.P. (2020) 'Investigating the relationship between service quality and customer satisfaction of BKash in Bangladesh', Int. J. Financial Services Management, Vol. 10, No. 1, pp.1-17.

Biographical notes: Abdul Gaffar Khan is an Assistant Professor at the Faculty of Business Studies and Department of Business Administration, Mawlana Bhashani Science and Technology University, Bangladesh. He obtained BBA and MBA degrees in Management from Islamic University, Bangladesh. He has been working as a Faculty Member from 2012. His research interests focus on the areas of organisation behaviour, management information systems, and knowledge management. He has published some research papers in renowned national and international journals.

Md. Shahed Mahmud is an Assistant Professor of Business Administration at Mawlana Bhashani Science and Technology University (MBSTU), Tangail, Bangladesh. His research interests include service marketing, management information systems and tourism development. 
Reshma Pervin Lima is an Assistant Professor of Business Administration at Mawlana Bhashani Science and Technology University (MBSTU), Tangail, Bangladesh. Her research interests include corporate finance, financial institution, and markets.

\section{Introduction}

In recent decades, the financial sector especially the banking sector has been going through enormous changes with the widespread use of modern technologies (Koksal, 2016; Leung and Matanda, 2013; Mortimer et al., 2015). These groundbreaking changes not only threatened the traditional banking channel but also reshaped the entire financial sector and produce a tremendous pressure on the supply side to develop innovative products and services for the customers. Whatever the innovative service offered by the financial institutions, which is essentially simple, compatible, personalised having inbuilt fast and secure access quality (Boonsiritomachai and Pitchayadejanant, 2017; Shaikh and Karjaluoto, 2015). With the increasing of competition in the financial industry especially banking sector, new forms of Financial Technology (Fin-Tech) related services have emerged in recent years. In these circumstances, customer self-service channels like ATMs, internet banking and mobile banking services are getting popular among the mass customers (Boonsiritomachai and Pitchayadejanant, 2017; Thakur, 2014). The transformation occurs in terms of providing convenient, affordable, and easily accessible services to bank customers (Chawla and Joshi, 2018). E-banking is one of the innovative technologies which provides convenient, speedy and dependable service to the customers (Boonsiritomachai and Pitchayadejanant, 2017; Nupur, 2010). In recent years, mobile banking (a special type of e-banking) service ranked top among the clients of the banks (Rahman et al., 2017). The mobile banking services are not only getting acceptance among the existing customers of the banks but also getting popularity among those areas or people where mainstream financial services were not touched yet (Shahin, 2016).

After the independence of Bangladesh in 1971, the establishment of Bangladesh's financial architecture started developing within the public sector institutions. Over the last four decades, several new generations of private banks emerged and the financial sector of Bangladesh is mostly dominated by the commercial banks in terms of asset and liabilities (Parvez et al., 2015). In September 2011, the authorities of Bangladesh gave permission to operate mobile banking in Bangladesh. Till then, Bangladesh has shown substantial growth in the adoption of mobile banking. Right now, 16 banks offer mobile banking services in the mobile banking industry of Bangladesh and that represents more than $0.8 \%$ of the total registered mobile banking accounts globally (Bangladesh Bank, 2019; Woodard, 2016). The increasing number of mobile phone users and wide coverage of mobile phone network has made their delivery channel an imperative tool-of-the-trade for spread out banking services to the unbanked or banked people (Bangladesh Bank, 2017). A USAID led project research findings shows that, in Bangladesh, most of the mobile banking users use mobile banking services for bill payments, savings, airtime recharge, education fee payments and merchant payments; furthermore, the research also showed that, people with both bank and mobile banking accounts are generally using the 
two accounts at the same time (Parvez et al., 2015). The research findings just represented the popularity of mobile banking in the context of Bangladesh which witnesses a steady growth in the last couple of years (Uddin, 2017). Data released (June, 2019) by Bangladesh Bank showed that 16 banks with total 934,195 number of agents are currently providing the mobile banking services to 32.458 million active mobile banking accounts (registered clients 72.05 million) where, the average daily transaction is $\$ 10,569.5$ million (Bangladesh Bank, 2019). Among the 16 banks, BRAC Bank's subsidiary BKash is the market leader in this segment. Nearly $60 \%$ of market share is owned by BKash, and subsequently Rocket (a subsidiary of Dutch-Bangla Bank Limited) owned nearly $20 \%$ of the total market share of mobile banking industry of Bangladesh (Mahbub, 2016). BKash's initial growth of large scale has been among the fastest globally and in Bangladesh in addition, most of the mobile banking users use BKash as a primary choice for mobile banking transaction in Bangladesh (Chen and Rasmussen, 2014).

In this modern digitalised age, ensuring superior service quality is one of the greatest challenges for any organisation (Farooq et al., 2018; Namukasa, 2013; Ong and Tan, 2010). The nature of the service gave a special room for the researchers in the service industry to test and retest the relationship between service quality and customer satisfaction (Farooq et al., 2018). The financial economy like Bangladesh deserves more and more research in the field of service marketing as the quality of delivering service by the financial institutions is not up to the mark. Thus, some of the researchers already conducted some research on overall customer satisfaction on banks (Karim and Chowdhury, 2014; Nupur, 2010; Rahaman et al., 2011; Rashid and Hassan, 2009; Siddiqi, 2011) but other research has especially focused on mobile banking segment. However, there exists some gap between service quality and customer satisfaction on mobile banking in Bangladesh. Therefore, an initiative has been taken to address the issue by using the SERVQUAL model. SERVQUAL model is one of the popular instruments used to measure the quality of services. In various service settings, social situations and geographic settings a number of studies adopted this model and got a substantial outcome (Amiri Aghdaie and Faghani, 2012). For the purpose of ensuring superior customer value, there remains only one option. That is enhancing customer service to gain overall customer satisfaction. To address this issue, this study aims to address the relationship between service quality (i.e. Tangibility, Reliability, Responsiveness, Assurance and Empathy) and customer satisfaction of mobile banking in light of BKash, and also to deliver some enhanced understanding and prominent propositions of how the quality of mobile banking services made available through handheld devices to uplift the overall service quality of mobile banking in light of BKash in Bangladesh. Bank marketing, relationship marketing and also service quality literature will be examined in this study.

The rest of this article is organised as follows: the next section provides the related literature followed by the research objectives and the research methodology. The successive sections present the empirical analysis, discussion, and findings. The article concludes with managerial implications, limitations, and scope for future research. 


\section{Review of previous studies}

For the measurement of service quality SERVQUAL model has been considered as the most reliable and widely acceptable model all over the world. Initially, ten dimensions (reliability; responsiveness; competence; access; courtesy; communication; credibility; security; understanding the customer; and tangibles) were listed for the measurement of service quality. Later on, in the year of 1988, these ten dimensions were shortlisted to five dimensions (tangibility, reliability, responsiveness, assurance and empathy). According to Parasuraman et al. $(1985,1988$, p.23) five principal dimensions that customers use to judge service quality include: tangibles, reliability, responsiveness, assurance and empathy. The definition is somehow like the following:

1 Tangibility refers to physical facilities, equipment, employees and communication tools.

2 Reliability refers to the ability to fulfil the promises correctly and assuredly.

3 Responsiveness refers to the service provider's intention and enthusiasm to aid the customers and to outline the immediate services.

4 Assurance refers to the employees' knowledge and humbleness and ability to convey trust and sincerity.

5 Empathy refers to providing personal care and attention to the customer.

\subsection{Service quality and customer satisfaction}

Boonsiritomachai and Pitchayadejanant (2017) conducted a study on determinants affecting mobile banking adoption by generation $\mathrm{Y}$ based on the Unified Theory of Acceptance and Use of Technology Model modified by the Technology Acceptance Model concept. The authors reveal that the revised model had a good fit in the context of mobile banking adoption by generation Y. In addition, the hedonic motivation of mobile banking users was identified as the most important factor motivating customers to adopt mobile banking, whereas mobile banking system security had a negative relationship with hedonic motivation.

Hai and Rahman (2016) revealed that the overall satisfaction level of the users of Mobile Financial Services (MFS) in Bangladesh is to some extent satisfactory. The results from their analysis also showed that there are significant differences in satisfaction levels among the mobile financial service user groups in terms of service providers' commitment, speed, and sincerity, and these differences are insignificant in terms of service users' income and convenience.

In their study, Masrek et al. (2014) highlighted that all of the three technologies used in their research, trusts has a positive relationship with mobile banking satisfaction. The finding further indicates the importance and significance of technology trust in predicting mobile banking satisfaction.

Amiri Aghdaie and Faghani (2012) used SERVQUAL model for measuring customer satisfaction in mobile banking services in Iran. The results showed that the four variables tangible, reliability, responsiveness and empathy would correlate with satisfaction significantly. Though, the assurance factor would have no relationship with customer 
satisfaction. The statistical tests of the study showed that there is a strong correlation exists between mobile banking services and customer satisfaction.

Shareef et al. (2018) conducted a study titled,' Consumer adoption of mobile banking services: An empirical examination of factors according to adoption stages'. The results revealed that driving factors of consumers' behavioural intentions to adopt mobile banking at the static, interaction and transaction service phases are significantly different, providing important theoretical and practical contributions.

Laforet and $\mathrm{Li}(2005)$ conducted a study aiming to investigate the market status for online/mobile banking in China. The results showed that Chinese online and mobile bank users were predominantly males, not necessarily young and highly educated, in contrast with the electronic bank users in the West. The barriers to mobile banking adoption were lack of awareness and understanding of the benefits provided by mobile banking.

In another study, Farah et al. (2018) found that most of the predictors of intention, including perceived value, performance expectancy, habit, social influence, effort expectancy, hedonic motivation (except for facilitating condition), perceived risk and trust, are significant. All predictors of usage behaviour are significant.

Based on the above study and investigation of literature no prominent works have been found, which analyse directly on the customer satisfaction of BKash using SERVQUAL model in Bangladesh. Therefore, an initiative has been taken to address the issue which will furthermore support the decision-maker to take a decision on the basis of these research findings.

\subsection{Research questions}

1 How do service qualities affect customer satisfaction?

2 How can service qualities be improved?

\subsection{Objectives of the study}

The objectives of the study are as follows:

1 To examine the relationship between constructs of service quality and overall satisfaction of customers of BKash.

2 To prescribe some remarkable suggestions to raise service quality of BKash.

\subsection{Theoretical framework and hypothesis development}

On the basis of the above literature review, there are five dimensions of SERVQUAL model of mobile banking. It consisted of tangibility, reliability, responsiveness, assurance and empathy. Service quality has enhanced the customer satisfaction of mobile banking which developed hypothesis through reviewing literature.

a Tangibility and customer satisfaction: Tangibles pertain to the appearance of the establishment's physical facilities, equipment, and personnel (Lee and Johnson, 1997; Wilson et al., 2016). Thus, tangibles are used by service providers to provide best services as well as to communicate by their equipment, personnel and other 
facilities to customers. On the other hand, the intangibles of mobile banking services are difficult to measure. Finally, it can measure the level of customer satisfaction. Thus, it can be hypothesised as follows:

H1: Tangibility (TAN) has a significantly positive influence on Customer Satisfaction (CS).

b Reliability and customer satisfaction: Reliability refers to the ability of service providers to offer promised service dependably and accurately. In general sense, reliability means that an organisation delivers on its promises such as promises about service provision, pricing, delivery and problem solving (Jordaan and Prinsloo, 2001; Lee and Johnson, 1997; Wilson et al., 2016). There is a certain effect of service quality on customer satisfaction. So this hypothesis was formulated.

H2: Reliability (REL) has a significantly positive influence on Customer Satisfaction (CS).

c Responsiveness and customer satisfaction: Responsiveness refers to the willingness of the service providers to help customers and provide prompt service. This dimension emphasises attentiveness and promptness in dealing with customer questions, requests, problems and complaints (Lee and Johnson, 1997; Wilson et al., 2016). Responsiveness is communicated to customers by the length of time they have to wait for assistance, answers to questions, or attention to problems. That is to say that service quality may be enhanced through responsiveness (Zeithaml and Bitner, 2003).

H3: Responsiveness (RES) has a significantly positive influence on Customer Satisfaction (CS).

$\mathrm{d}$ Assurance and customer satisfaction: Assurance involves the knowledge and courtesy of employees and also their ability to express confidence and trust. This dimension becomes important when patrons feel uncertain about the service offerings of a particular restaurant (Wilson et al., 2016). Assurance may be ensured service provider if patrons are able to develop trust and to feel confident about mobile banking services without fear of insult or recrimination. Customers can also be satisfied by this assurance dimensions.

H4: Assurance (ASS) has a significantly positive influence on Customer Satisfaction (CS).

e Empathy and customer satisfaction: Empathy is the caring and individualised attention to provide its customers. The essence of empathy is by conveying, through personalised service, that customers are special and unique (Wilson et al., 2016). Customers want to feel important and understood by the organisations that provide services to them. Employees in BKash may show empathy to customers by sound behaviour, sympathetically and politely.

H5: Empathy (EMP) has a significantly positive influence on Customer Satisfaction $(C S)$. 
Figure 1 Proposed research model

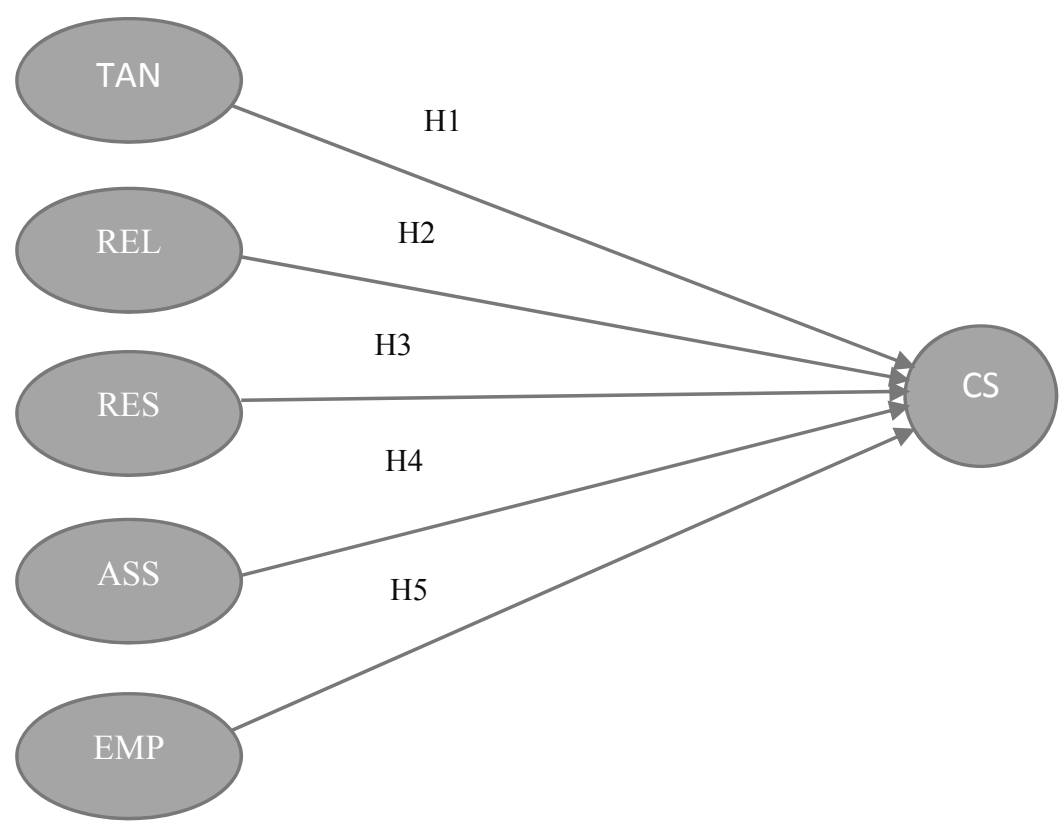

Note: $\quad$ TAN $=$ Tangibility, REL $=$ Reliability, RES $=$ Responsiveness, ASS $=$ Assurance, $\mathrm{EM}=$ Empathy, $\mathrm{CS}=$ Customer satisfaction.

\section{Methodology}

\subsection{Research setting}

Most of the services of mobile banking cover urban to rural areas in Bangladesh. Modern business and rural peoples are mostly using mobile banking services. Owing the cost-effectiveness a convenience sampling method was used to select potential participants in this study. In this study were randomly selected two districts (Dhaka and Tangail) of Bangladesh for collecting data from potential respondents.

\subsection{Questionnaire design and data collection}

The structured survey questionnaire method was used to collect the relevant data for evaluating the latent constructs in the developed model. The questionnaire was divided into two parts. Part A contains demographic information, which was sought to represent the descriptive characteristics of the respondents. The respondents were asked to provide information regarding their gender, age, educational qualifications, income level, transactions time and frequent used service. Part B includes questions regarding the five independent SERVQUAL dimensions and one dependent constructs in the developed research model using a 5-point Likert scale ranging from (1) "strongly disagree" to (5) "strongly agree." The questionnaire was initially developed in English and the valid questionnaire was translated into Bengali by the expert translator. Then, a pilot study was 
conducted to test the effectiveness of the final questionnaire. The study distributed 400 self-administered questionnaires, and 312 were returned, resulting in $78 \%$ response rate. Twenty incomplete questionnaires were excluded from the analysis. Thus, 292 questionnaires were selected for final analysis.

\subsection{Statistical analysis}

The analysis of "Partial Least Square-Structural Equation Modelling (PLS-SEM)" using SPSS-23 and Smart-PLS 3.0 software was performed frequency analysis, to test and validate the proposed model and the testing hypothesis among hypothesised constructs.

\section{Results and analysis}

\subsection{Demographic information}

The demographic characteristics of the respondents are presented in Table 1. From the survey analysed, (73.6\%) were males, and $(26.4 \%)$ were females. The majority ages of the respondents were $20-30(76.0 \%)$ of the respondents and the majorities' educational qualifications were bachelor's degree (63.7\%). On the other hand, the income levels of the respondents were less than 5000, almost half of the respondents. The majority of transactions times and services uses were monthly (54.1\%) and cash-out (65.1\%).

Table 1 Demographic characteristics of respondents

\begin{tabular}{|c|c|c|c|}
\hline \multicolumn{2}{|c|}{ Characteristics and its category } & \multirow{2}{*}{$\begin{array}{c}\text { Frequency } \\
215\end{array}$} & \multirow{2}{*}{$\frac{\text { Valid per cent }}{73.6}$} \\
\hline Gender & Male & & \\
\hline vendare & Female & 77 & 26.4 \\
\hline \multirow{5}{*}{ Age } & Less than 20 & 23 & 7.9 \\
\hline & $20-30$ & 222 & 76.0 \\
\hline & $30-40$ & 23 & 7.9 \\
\hline & $40-50$ & 14 & 4.8 \\
\hline & More than 50 & 10 & 3.4 \\
\hline \multirow{6}{*}{ Educational qualification } & Illiterate & 5 & 1.7 \\
\hline & Less than Secondary & 12 & 4.1 \\
\hline & Secondary & 20 & 6.8 \\
\hline & Higher Secondary & 36 & 12.3 \\
\hline & Bachelor's & 186 & 63.7 \\
\hline & Master's & 33 & 11.3 \\
\hline \multirow{5}{*}{ Income level } & Less than 5000 & 148 & 50.7 \\
\hline & $5000-10,000$ & 81 & 27.7 \\
\hline & $10,000-20,000$ & 38 & 13.0 \\
\hline & $20,000-30,000$ & 13 & 4.5 \\
\hline & 30,000 above & 12 & 4.1 \\
\hline
\end{tabular}


Table 1 Demographic characteristics of respondents (continued)

\begin{tabular}{clcc}
\hline Characteristics and its category & Frequency & Valid per cent \\
\hline \multirow{4}{*}{ Transaction time of BKash } & Every Day & 31 & 10.6 \\
& Weekly & 82 & 28.1 \\
& Monthly & 158 & 54.1 \\
& Quarterly & 21 & 7.2 \\
\hline & Cash In & 63 & 21.6 \\
& Cash Out & 190 & 65.1 \\
& Send Money & 13 & 4.5 \\
& Buy Airtime & 26 & 8.8 \\
\hline
\end{tabular}

\subsection{Reliability and validity analysis}

Table 2 and Figure 2 show the measurement model which was assessed by examining the indicator reliability, internal consistency reliability, convergent validity, and discriminant validity (Hair et al., 2016). The indicator reliability was examined by squaring each of outer loading and its threshold is 0.5 or higher (Hulland, 1999). The internal consistency reliability was evaluated by examining composite reliability, and a level of 0.70 was considered an indicator of acceptable internal consistency (Hair et al., 1995). The constructs with an Average Variance Extracted (AVE) of at least 0.50 can be assumed to present convergent validity, and a similar assumption can be made if the item loading is well above 0.50 . Table 2 shows the indicators loading, composite reliability, and AVE obtained in this study. Thus the calculated indicator loadings composite reliability has a value greater than the threshold value of .70. As per results, each of the constructs supports reliability. Furthermore, Table 2 also shows that the estimated AVE ranges ( 0.60 to 0.72$)$ are greater than the recommended value .50 . Therefore, the conditions for convergent validity are satisfied in this study. The model explains $69.7 \%$ of the variance in customer satisfaction to BKash.

Table 2 Measurement model

\begin{tabular}{lccccc}
\hline Constructs & Items & $\begin{array}{c}\text { Indicators } \\
\text { loading }\end{array}$ & AVE $^{b}$ & $\begin{array}{c}\text { Composite }^{a} \\
\text { reliability }\end{array}$ & $R_{\text {Square }}$ \\
\hline Tangibility & $\mathrm{T} 1$ & 0.884 & 0.723 & 0.839 & 0 \\
\hline \multirow{2}{*}{ Reliability } & $\mathrm{T} 2$ & 0.815 & 0.764 & 0 \\
\hline \multirow{2}{*}{ Responsiveness } & Re3 & 0.827 & 0.618 & 0.822 & 0 \\
& Res1 & 0.763 & & 0.605 \\
\hline
\end{tabular}


Table 2 Measurement model (continued)

\begin{tabular}{lccccc}
\hline \multirow{2}{*}{ Empathy } & E1 & 0.771 & & & 0.82 \\
& E2 & 0.751 & 0.603 & 0 \\
\hline Customer Satisfaction & OS & 0.808 & & & 0.697 \\
\hline
\end{tabular}

Notes: $\quad$ AVE $=$ average variance extracted, ${ }^{\mathrm{a} C o m p o s i t e}$ Reliability $=(\Sigma$ factor loading $)$

$2 /\left(\left(\Sigma\right.\right.$ factor loading) $2+\Sigma$ (variance of error)); ${ }^{\mathrm{b}} \mathrm{AVE}=\Sigma$ (factor loading)

$2 /((\Sigma$ (factor loading) $2+\Sigma$ (variance of error) $)$

Figure 2 Proposed research model validation with path efficient

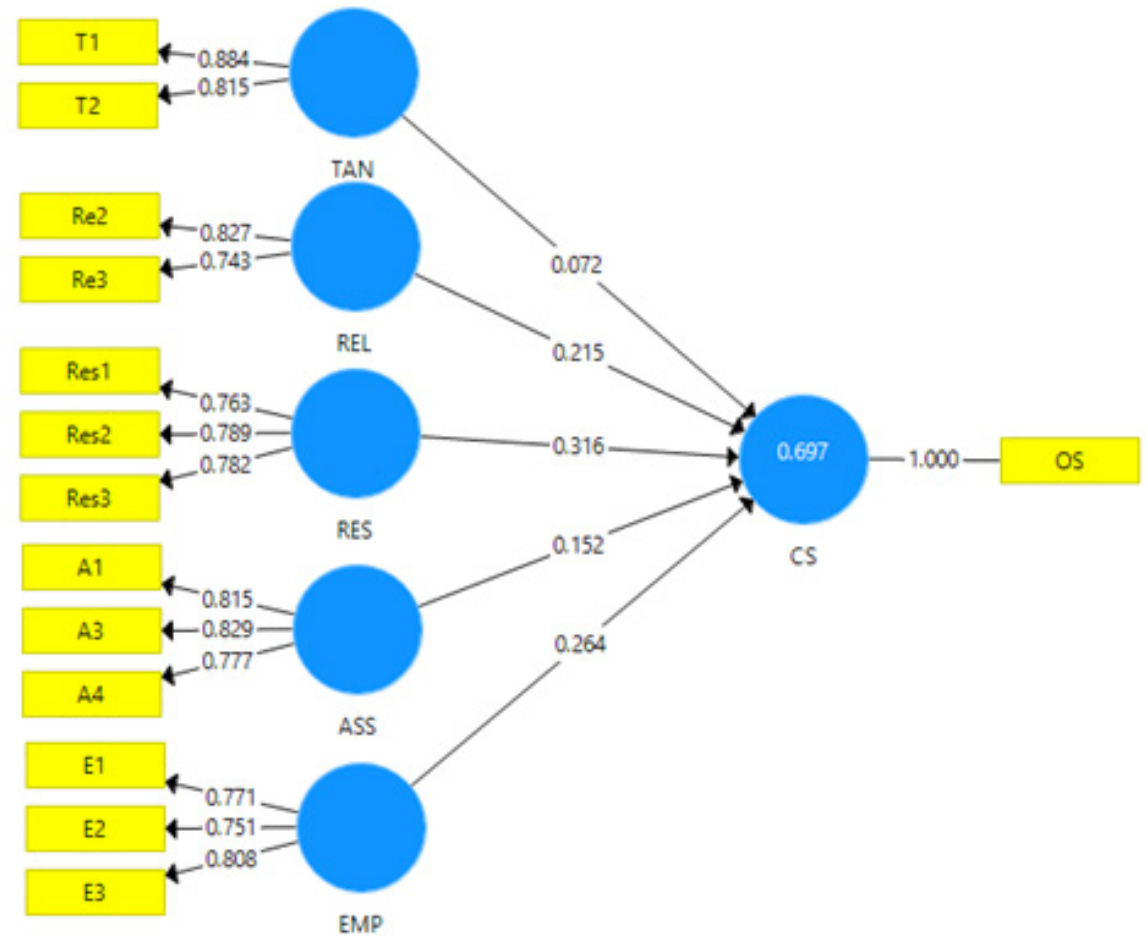

The discriminant validity was assessed by the correlation matrix and the square root of the AVE and cross-loading matrix. For satisfactory discriminant validity, the square root of the AVE of a construct should be greater than its correlation with other constructs (Henseler et al., 2009). On the other hand, outer loading of a construct should be larger than it's others corresponding loadings. However, the calculated cross-loading from Table 3 is an exhibit that all outer loading is larger than its corresponding loadings. The calculated square root of AVE, which is shown in Table 4, was greater than the corresponding correlation, confirming the discriminant validity of the data. So the validity of the data has been fulfilled and satisfied for further analysis. 
Table 3 Cross loading matrix for discriminant validity analysis

\begin{tabular}{lcccccc}
\hline Items & $A S S$ & $C S$ & $E M P$ & REL & RES & TAN \\
\hline A1 & 0.815 & 0.604 & 0.514 & 0.474 & 0.526 & 0.249 \\
A3 & 0.829 & 0.568 & 0.52 & 0.476 & 0.662 & 0.212 \\
A4 & 0.777 & 0.478 & 0.518 & 0.383 & 0.531 & 0.246 \\
E1 & 0.557 & 0.554 & 0.771 & 0.424 & 0.536 & 0.288 \\
E2 & 0.424 & 0.534 & 0.751 & 0.449 & 0.486 & 0.262 \\
E3 & 0.507 & 0.571 & 0.808 & 0.442 & 0.476 & 0.284 \\
OS & 0.686 & 1 & 0.712 & 0.665 & 0.749 & 0.337 \\
Re2 & 0.557 & 0.565 & 0.52 & 0.827 & 0.642 & 0.179 \\
Re3 & 0.295 & 0.476 & 0.356 & 0.743 & 0.33 & 0.158 \\
Res1 & 0.482 & 0.585 & 0.415 & 0.484 & 0.763 & 0.195 \\
Res2 & 0.668 & 0.609 & 0.581 & 0.486 & 0.789 & 0.234 \\
Res3 & 0.501 & 0.551 & 0.502 & 0.511 & 0.782 & 0.157 \\
T1 & 0.284 & 0.315 & 0.327 & 0.146 & 0.234 & 0.884 \\
T2 & 0.204 & 0.254 & 0.279 & 0.23 & 0.193 & 0.815 \\
\hline
\end{tabular}

Note: $\quad \mathrm{ASS}=$ Assurance, $\mathrm{CS}=\mathrm{OS}=$ Customer satisfaction, $\mathrm{EMP}=$ Empathy,

RES $=$ Responsiveness, TAN $=$ Tangibility.

Table 4 Latent constructs correlation matrix and the square root of the AVE

\begin{tabular}{lcccccc}
\hline Items & ASS & CS & EMP & REL & RES & TAN \\
\hline ASS & 0.807 & & & & & \\
CS & 0.686 & 1 & & & & \\
EMP & 0.64 & 0.712 & 0.777 & & & \\
REL & 0.554 & 0.665 & 0.564 & 0.786 & & \\
RES & 0.71 & 0.749 & 0.643 & 0.634 & 0.778 & \\
TAN & 0.291 & 0.337 & 0.358 & 0.215 & 0.253 & 0.85 \\
\hline
\end{tabular}

\subsection{Hypothesis testing}

The study used a structural equation model to identify relationships among the constructs in this study. From the confirmation of the construct variables validity and reliability, the structural model was tested and the hypotheses were also examined. Using both the PLS algorithm and bootstrapping algorithm, all the path coefficients and $t$-values were estimated at 5\% and $1 \%$ level of significance. Table 5 shows the findings among construct variables relationship. The findings showed that the relationships between Tangibility and Customer Satisfaction $(t=2.07, \beta=0.072, p>0.05)$, Reliability and Customer Satisfaction $(t=4.81, \beta=0.215, p<0.01)$, Responsiveness and Customer Satisfaction $(t=6.342, \beta=0.316, p>0.01)$, Assurance and Customer Satisfaction $(t=3.15, \beta=0.152, p>0.01)$, Empathy and Customer Satisfaction $(t=5.878, \beta=0.264$, $p>0.01)$ were found positive and significant. Thus, the entire hypotheses were found supported in this research. Furthermore, Figure 3 portrays that the hypothesis testing among the constructs wasvalid. 
Table 5 Structural model

\begin{tabular}{cccccc}
\hline Hypothesis & Paths & $\begin{array}{c}\text { Original sample } \\
(O), \beta\end{array}$ & $\begin{array}{c}T \\
\text { Statistics }\end{array}$ & P-values & Decision \\
\hline H1 & TAN $\rightarrow$ CS & 0.072 & 2.070 & 0.039 & Supported \\
H2 & REL $\rightarrow$ CS & 0.215 & 4.810 & 0.000 & Supported \\
H3 & RES $\rightarrow$ CS & 0.316 & 6.342 & 0.000 & Supported \\
H4 & ASS $\rightarrow$ CS & 0.152 & 3.150 & 0.002 & Supported \\
H5 & EMP $\rightarrow$ CS & 0.264 & 5.878 & 0.000 & Supported \\
\hline
\end{tabular}

Figure 3 Bootstrapping results for hypothesis testing validation

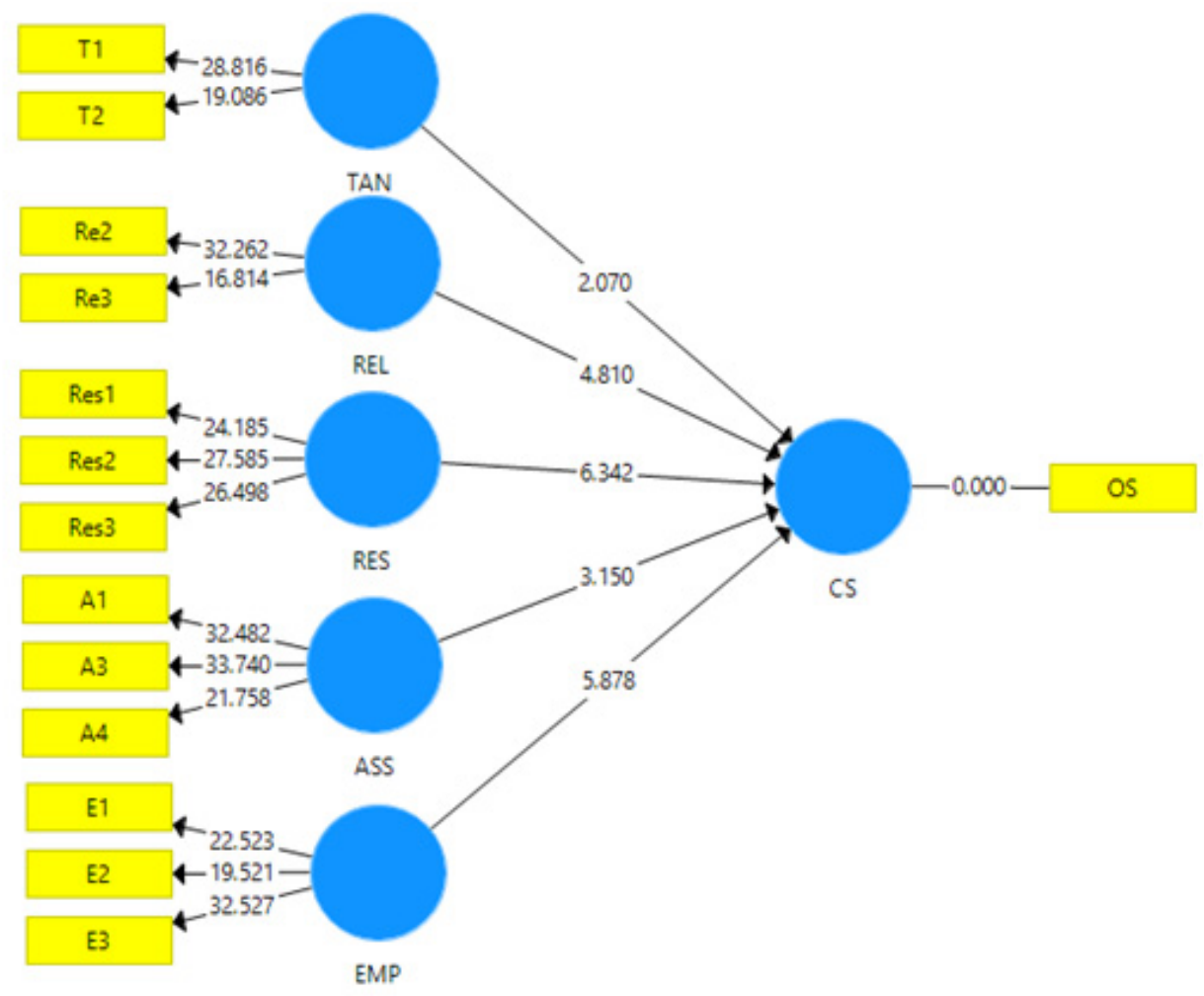

\section{Discussions}

This study applied the SERVQUAL model to assess the relationship between service quality and customer satisfaction of BKash in Bangladesh. The empirical findings of this study provide rigorous information regarding services quality and customer satisfaction of mobile banking in Bangladesh in light of BKash. The finding is unique through structural equation modelling because it introduces and validates the measurement and structural model. This study establishes that all the dimensions of service quality have a 
significant impact on overall customer services. Specifically, the RES and EMP have the strongest significant impact factor for customer satisfaction whereas the TAN $(\beta=.072)$ has the lowest impact of service quality of mobile banking in Bangladesh. In addition, REL and ASS have a positive significant impact on service quality. Most of the customers are expecting to get the highest services in REL and ASS. All the dimensions of service quality have a significant relationship with customer satisfaction except TAN with a $99 \%$ confidence level. TAN has also significant relation with a $95 \%$ confidence level. Theoretically, this model will help the policymakers of financial institutions, government agencies, and researchers. In addition, this result will be beneficial for banks and government authority to take a business policy for the related sectors too. The service provider should also pay attention to Corporate Social Responsibility (CSR) and environmental management activities that could help enhance the mobile banking image and, thus, perceived service quality and customer satisfaction in the eyes of their customers.

\section{Limitations and future research directions}

This study was conducted on only a small sample from Tangail and Dhaka districts in Bangladesh. So the findings may not be representative of the entire population. The future research should focus on generalisation of service quality and customer satisfaction. The potential future research can study the moderating effect of culture and socio-economic conditions on the relationship between service quality and customer satisfaction. Another limitation of the study is that it covered only one mobile banking service provider i.e. BKash. Future research should cover more of the mobile banking service providers in Bangladesh.

\section{Conclusion and recommendations}

The aim of this study is to make a contribution to understanding the fundamental dimensions of mobile banking (i.e. BKash) service quality in Bangladesh. For this, SEM is employed to get SERVQUAL dimensions significant to Bangladeshi consumers. The respondents pointed out tangibility, reliability, responsiveness, empathy and assurance as important dimensions affecting service quality on customer satisfaction in mobile banking. As a conclusion, this study reveals that all the variables of service quality of BKash have significant associations with customer satisfaction. In addition to that, the research findings reveal that, tangibility has the less significance than the other four variables (i.e. reliability, responsiveness, empathy, and assurance). Particularly, in this scenario, tangibility has a very light effect on customer satisfaction. Moreover, a tangibility dimension is not important for the customers because it involves technological and other infrastructural materials (i.e. physical facilities and equipment, etc.). The researcher suggests that reliability is the vital dimension in the quality of this service that will mostly affect the perception of Bangladeshi customers. Consequently, the service provider needs to pay more attention to raise the reliability of services of mobile banking among consumers. Thus, the service provider should ensure the security and promptness 
of services. On the other hand, all of the customers are feeling the problem with high costs. The service provider also should take some initiative to reach a reasonable cost. The results also found that most of the male 20-30 aged low-income respondents are using the services of BKash. Thus, the improvement of service quality may lead to increase customer satisfaction. In addition, this study also suggests a number of implications for mobile banking service providers in Bangladesh. Hence, this study provides some directions for further research in this field.

\section{References}

Amiri Aghdaie, S. and Faghani, F. (2012) 'Mobile banking service quality and customer satisfaction (application of SERVQUAL model)', International Journal of Management and Business Research, Vol. 2, No. 4, pp.351-361.

Bangladesh Bank. (2017) Mobile Financial Services. Available online on: https://www.bb.org.bd/ fnansys/paymentsys/mobilefin.php

Bangladesh Bank. (2019) Mobile Financial Services (MFS). Available online on: https://www.bb.org.bd/fnansys/paymentsys/mfsdata.php

Boonsiritomachai, W. and Pitchayadejanant, K. (2017) 'Determinants affecting mobile banking adoption by generation $\mathrm{Y}$ based on the unified theory of acceptance and use of technology model modified by the technology acceptance model concept', Kasetsart Journal of Social Sciences, Vol. 4, No. 2, pp.349-358. doi: 10.1016/j.kjss.2017.10.005.

Chawla, D. and Joshi, H. (2018) 'The moderating effect of demographic variables on mobile banking adoption: an empirical investigation', Global Business Review, Vol. 19, No. 3, pp.S90-S113.

Chen, G. and Rasmussen, S. (2014) bKash Bangladesh: A Fast Start for Mobile Financial Services. World Bank, Washington, DC. Available online at: http://hdl.handle.net/10986/20262

Farah, M.F., Hasni, M.J.S. and Abbas, A.K. (2018) 'Mobile-banking adoption: empirical evidence from the banking sector in Pakistan', International Journal of Bank Marketing, Vol. 36, No. 7 , pp.1386-1413.

Farooq, M.S., Salam, M., Fayolle, A., Jaafar, N. and Ayupp, K. (2018) 'Impact of service quality on customer satisfaction in Malaysia airlines: a PLS-SEM approach', Journal of Air Transport Management, Vol. 67, pp.169-180.

Hai, M.A. and Rahman, M.M. (2016) 'Measuring the satisfaction levels of mobile financial services users in Bangladesh: an empirical study', International Journal of Online Marketing (IJOM), Vol. 6, No. 1, pp.24-33.

Hair, J.F., Anderson, R.E., Tatham, R.L. and Black, W.C. (1995), Multivariate Data Analysis with Readings, 4th ed., Prentice Hall, New Jersy.

Hair, J.F., Hult, G.T.M., Ringle, C. and Sarstedt, M. (2016) A Primer on Partial Least Squares Structural Equation Modeling (PLS-SEM), Sage Publications.

Henseler, J., Ringle, C.M. and Sinkovics, R.R. (2009) 'The use of partial least squares path modeling in international marketing', New Challenges to International Marketing, Emerald Group Publishing Limited, pp.277-319.

Hulland, J. (1999) 'Use of partial least squares (PLS) in strategic management research: a review of four recent studies', Strategic Management Journal, pp.195-204.

Jordaan, Y. and Prinsloo, M. (2001) Grasping Service Marketing, Grapevine News.

Karim, R. and Chowdhury, T. (2014) 'Customer satisfaction on service quality in private commercial banking sector in Bangladesh', British Journal of Marketing Studies, Vol. 2, No. 2, pp.1-11. 
Koksal, M.H. (2016) 'The intentions of Lebanese consumers to adopt mobile banking', International Journal of Bank Marketing, Vol. 34, No. 3, pp.327-346.

Laforet, S. and Li, X. (2005) 'Consumers' attitudes towards online and mobile banking in China', International Journal of Bank Marketing, Vol. 23, No. 5, pp.362-380. Doi:10.1108/ 02652320510629250.

Lee, M. and Johnson, K.K. (1997) 'Customer expectations for service at apparel retail outlets', Journal of Family and Consumer Sciences, Vol. 89, No. 4, p.26.

Leung, L.S.K. and Matanda, M.J. (2013) 'The impact of basic human needs on the use of retailing self-service technologies: a study of self-determination theory', Journal of Retailing and Consumer Services, Vol. 20, No. 6, pp.549-559.

Mahbub, I. (2016) Top Mobile Money Services in Bangladesh by Market Share. Available online at: http://futurestartup.com/2016/08/16/top-mobile-money-services-bangladesh-market-share/

Masrek, M.N., Mohamed, I.S., Daud, N.M. and Omar, N. (2014) 'Technology trust and mobile banking satisfaction: a case of Malaysian consumers', Procedia - Social and behavioral Sciences, Vol. 129, pp.53-58.

Mortimer, G., Neale, L., Hasan, S.F.E. and Dunphy, B. (2015) 'Investigating the factors influencing the adoption of m-banking: a cross cultural study', International Journal of Bank Marketing, Vol. 33, No. 4, pp.545-570.

Namukasa, J. (2013) 'The influence of airline service quality on passenger satisfaction and loyalty: the case of Uganda airline industry', The TQM Journal, Vol. 25, No. 5, pp.520-532.

Nupur, J.M. (2010) 'E-banking and customers' satisfaction in Bangladesh: an analysis', International Review of Business Research Papers, Vol. 6, No. 4, pp.145-156.

Ong, W.L. and Tan, A.K. (2010) 'A note on the determinants of airline choice: the case of Air Asia and Malaysia airlines', Journal of Air Transport Management, Vol. 16, No. 4, pp.209-212.

Parasuraman, A., Zeithaml, V.A. and Berry, L.L. (1985) 'A conceptual model of service quality and its implications for future research', The Journal of Marketing, pp.41-50.

Parasuraman, A., Zeithaml, V.A. and Berry, L.L. (1988) 'A multiple item scale for measuring consumer perceptions of service quality', Journal of Retailing, Vol. 64, No. 1, pp.12-40.

Parvez, J., Islam, A. and Woodard, J. (2015) Mobile Financial Services in Bangladesh, Technical Report, United States Agency for International Development (USAID).

Rahaman, M.M., Abdullah, M. and Rahman, A. (2011) 'Measuring service quality using SERVQUAL model: a study on PCBs (private commercial banks) in Bangladesh', Business Management Dynamics, Vol. 1, No. 1, pp.1-11.

Rahman, A., Hasan, M. and Mia, M.A. (2017) 'Mobile banking service quality and customer satisfaction in Bangladesh: an analysis', The Cost and Management, Vol. 45, No. 2, pp.25-32.

Rashid, M. and Hassan, M.K. (2009) 'Customer demographics affecting bank selection criteria, preference, and market segmentation: study on domestic Islamic banks in Bangladesh', International Journal of Business and Management, Vol. 4, No. 6, pp.131-146.

Shahin, A. (2016) What can we Learn From M-Pesa and bKash? Available online at: http://www.novatti.com/learn-m-pesa-bkash-27-04-2016/

Shaikh, A.A. and Karjaluoto, H. (2015) 'Mobile banking adoption: a literature review', Telematics and Informatics, Vol. 32, No. 1, pp.129-142. Doi: 10.1016/j.tele.2014.05.003.

Shareef, M.A., Baabdullah, A., Dutta, S., Kumar, V., Dwivedi, Y.K. (2018) 'Consumer adoption of mobile banking services: an empirical examination of factors according to adoption stages', Vol. 43, pp.54-67.

Siddiqi, K.O. (2011) 'Interrelations between service quality attributes, customer satisfaction and customer loyalty in the retail banking sector in Bangladesh', International Journal of Business and Management, Vol. 6, No. 3, p.12-36. 
Thakur, R. (2014) 'What keeps mobile banking customers loyal?', International Journal of Bank Marketing, Vol. 32, No. 7, pp.628-646. Doi: 10.1108/IJBM-07-2013-0062.

Uddin, N. (2017) Mobile Financial Service 101: Major Trends in MFS in Bangladesh. Available online at: http://futurestartup.com/2017/02/14/mobile-financial-service-101-major-trends-inmfs-in-bangladesh/

Wilson, A., Zeithaml, V., Bitner, M. J. and Gremler, D. (2016) 'Services Marketing: Integrating Customer Focus Across the Firm, McGraw Hill.

Woodard, J. (2016) The Current State of Mobile Financial Services in Bangladesh. Available online at: http://www.ictworks.org/2016/10/12/the-current-state-of-mobile-financial-servicesin-bangladesh/

Zeithaml, V.A. and Bitner, M.J. (2003) 'Services Marketing: Integrating Customer Focus Across the Firm, McGraw-Hill, Boston, New York. 
Appendix: Measurement items

\begin{tabular}{|c|c|c|c|}
\hline \multirow{15}{*}{$\begin{array}{l}\text { Parasuraman } \\
\text { et al. } \\
(1988, \text { p. } 23)\end{array}$} & Constructs & Items & Questions description \\
\hline & \multirow{2}{*}{$\begin{array}{l}\text { Tangibility } \\
\text { (TAN) }\end{array}$} & $\mathrm{T} 1$ & $\begin{array}{l}\text { Does the BKash have modern-looking and high- } \\
\text { tech equipment? }\end{array}$ \\
\hline & & $\mathrm{T} 2$ & $\begin{array}{l}\text { Does the BKash have visually appealing physical } \\
\text { facilities? }\end{array}$ \\
\hline & \multirow{2}{*}{$\begin{array}{l}\text { Reliability } \\
\text { (REL) }\end{array}$} & $\operatorname{Re} 2$ & $\begin{array}{l}\text { Do the BKash agents show a sincere interest in } \\
\text { solving problems when you face it? }\end{array}$ \\
\hline & & $\operatorname{Re} 3$ & $\begin{array}{l}\text { Does the BKash assure you an error-free } \\
\text { transaction? }\end{array}$ \\
\hline & \multirow{3}{*}{$\begin{array}{l}\text { Responsiveness } \\
\text { (RES) }\end{array}$} & Res1 & $\begin{array}{l}\text { Does the BKash agent provide prompt and } \\
\text { accurate service? }\end{array}$ \\
\hline & & Res2 & Are the BKash agents always willing to help you? \\
\hline & & Res3 & $\begin{array}{l}\text { Are the BKash agents take more time (more than } \\
\text { your expectation) to respond to your request? }\end{array}$ \\
\hline & \multirow{3}{*}{$\begin{array}{l}\text { Assurance } \\
\text { (ASS) }\end{array}$} & A1 & $\begin{array}{l}\text { Does the behaviour of the BKash agent } / \mathrm{s} \text { give } \\
\text { confidence to you? }\end{array}$ \\
\hline & & A3 & $\begin{array}{l}\text { Are the BKash agents friendly and courteous with } \\
\text { you? }\end{array}$ \\
\hline & & A4 & $\begin{array}{l}\text { Do the BKash agents have that much knowledge, } \\
\text { to answer your questions? }\end{array}$ \\
\hline & \multirow{3}{*}{$\begin{array}{l}\text { Empathy } \\
\text { (EMP) }\end{array}$} & E1 & $\begin{array}{l}\text { Does the BKash agent give you individual } \\
\text { attention? }\end{array}$ \\
\hline & & E2 & $\begin{array}{l}\text { Does the BKash have convenient operation hours } \\
\text { (call centre, query or other services)? }\end{array}$ \\
\hline & & E3 & $\begin{array}{l}\text { Do the BKash agents understand your specific } \\
\text { needs? }\end{array}$ \\
\hline & $\begin{array}{l}\text { Customer } \\
\text { Satisfaction } \\
\text { (CS) }\end{array}$ & OS & $\begin{array}{l}\text { Are you satisfied with the overall service quality } \\
\text { of BKash? }\end{array}$ \\
\hline
\end{tabular}

